\title{
Polygenic and multifactorial scores for pancreatic ductal adenocarcinoma risk prediction
}

\author{
Alice Alessandra Galeotti, ${ }^{1,2}$ Manuel Gentiluomo (D) ,' Cosmeri Rizzato, 2,3 \\ Ofure Obazee, ${ }^{2}$ John P Neoptolemos, ${ }^{4}$ Claudio Pasquali, ${ }^{5}$ Michael Nentwich, ${ }^{6}$ \\ Giulia Martina Cavestro, ${ }^{7}$ Raffaele Pezzilli, ${ }^{8}$ William Greenhalf, ${ }_{1}^{9}$ Bernd Holleczek, ${ }^{10,11}$

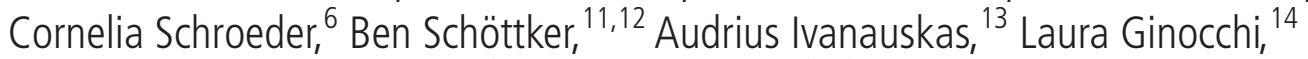 \\ Timothy J Key ${ }^{15}$ Péter Hegyi, ${ }^{16,17}$ Livia Archibugi, ${ }^{18,19}{ }^{19}$ Erika Darvasi, ${ }^{17}$ Daniela Basso, ${ }^{20}$ \\ Cosimo Sperti, ${ }^{21}$ Maarten F Bijlsma, ${ }^{22,23}$ Orazio Palmieri (D) , ${ }^{24}$ Viktor Hlavac, ${ }^{25}$ \\ Renata Talar-Wojnarowska, ${ }^{26}$ Beatrice Mohelnikova-Duchonova, ${ }^{27}$ Thilo Hackert, $^{4}$ \\ Yogesh Vashist, ${ }^{6}$ Ondrej Strouhal, ${ }^{27,28}$ Hanneke van Laarhoven, ${ }^{23,29}$ Francesca Tavano, ${ }^{24}$ \\ Martin Lovecek, ${ }^{30}$ Christos Dervenis, ${ }^{31}$ Ferenc Izbéki, ${ }^{32}$ Andrea Padoan, ${ }^{20}$ \\ Ewa Małecka-Panas, ${ }^{26}$ Evaristo Maiello, ${ }^{24}$ Giuseppe Vanella, ${ }^{18}$ Gabriele Capurso, ${ }^{18,19}$ \\ Jakob R Izbicki, ${ }^{6}$ George E Theodoropoulos, ${ }^{33}$ Krzysztof Jamroziak, ${ }^{34}$ Verena Katzke, ${ }^{35}$ \\ Rudolf Kaaks, ${ }^{35}$ Andrea Mambrini, ${ }^{14}$ Ioannis S Papanikolaou, ${ }^{36}$ Richárd Szmola, ${ }^{37}$ \\ Andrea Szentesi, ${ }^{16,17}$ Juozas Kupcinskas, ${ }^{13}$ Simona Bursi, ${ }^{14}$ Eithne Costello, ${ }^{9}$ \\ Ugo Boggi, ${ }^{38}$ Anna Caterina Milanetto, ${ }^{5}$ Stefano Landi, ${ }^{1}$ Maria Gazouli (i) ${ }^{39}$ \\ Ludmila Vodickova, ${ }^{40,41,42}$ Pavel Soucek, ${ }^{25}$ Domenica Gioffreda, ${ }^{24}$ Federica Gemignani, ${ }^{1}$ \\ Hermann Brenner, ${ }^{11,43,44}$ Oliver Strobel, ${ }^{4}$ Markus Büchler, ${ }^{4}$ Pavel Vodicka, ${ }^{40,41,42}$ \\ Salvatore Paiella, ${ }^{45}$ Federico Canzian, ${ }^{2}$ Daniele Campa ${ }^{1}$
}

- Additional material is published online only. To view please visit the journal online (http://dx.doi.org/10.1136/ jmedgenet-2020-106961).

For numbered affiliations see end of article.

Correspondence to

Dr Federico Canzian, Genome Epidemiology, German Cancer Research Center (DKFZ), Heidelberg 69120, Germany; f.canzian@dkfz.de

AAG and MG contributed equally.

$A A G$ and $M G$ are joint first authors.

FC and DC are joint last authors.

Received 26 February 2020 Revised 20 April 2020

Accepted 9 May 2020

Published Online First 26 June 2020

Check for updates

(C) Author(s) (or their employer(s)) 2021. No commercial re-use. See rights and permissions. Published by BMJ.

To cite: Galeotti AA Gentiluomo M, Rizzato C, et al. J Med Genet

2021:58:369-377.

\section{ABSTRACT}

Background Most cases of pancreatic ductal adenocarcinoma (PDAC) are asymptomatic in early stages, and the disease is typically diagnosed in advanced phases, resulting in very high mortality. Tools to identify individuals at high risk of developing PDAC would be useful to improve chances of early detection. Objective We generated a polygenic risk score (PRS) for PDAC risk prediction, combining the effect of known risk SNPs, and carried out an exploratory analysis of a multifactorial score.

Methods We tested the associations of the individual known risk SNPs on up to 2851 PDAC cases and 4810 controls of European origin from the PANcreatic Disease ReseArch (PANDoRA) consortium. Thirty risk SNPs were included in a PRS, which was computed on the subset of subjects that had $100 \%$ call rate, consisting of 839 cases and 2040 controls in PANDoRA and 6420 cases and 4889 controls from the previously published Pancreatic Cancer Cohort Consortium I-III and Pancreatic Cancer Case-Control Consortium genome-wide association studies. Additional exploratory multifactorial scores were constructed by complementing the genetic score with smoking and diabetes.

Results The scores were associated with increased PDAC risk and reached high statistical significance $\left(\mathrm{OR}=2.70,95 \% \mathrm{Cl} 1.99\right.$ to $3.68, \mathrm{p}=2.54 \times 10^{-10}$ highest vs lowest quintile of the weighted $P R S$, and $O R=14.37$, $95 \% \mathrm{Cl} 5.57$ to $37.09, p=3.64 \times 10^{-8}$, highest vs lowest quintile of the weighted multifactorial score).

Conclusion We found a highly significant association between a PRS and PDAC risk, which explains more than individual SNPs and is a step forward in the direction of the construction of a tool for risk stratification in the population.

\section{INTRODUCTION}

Pancreatic ductal adenocarcinoma (PDAC) is the most common form of pancreatic cancer and represents about $85 \%$ of total cases. ${ }^{1}$ Due to the lack of early symptoms for most patients, ${ }^{2}$ the lack of reliable biomarkers and the difficulty in imaging its initial development, ${ }^{3}$ PDAC is typically detected in advanced stages, ${ }^{1}$ when there is a shortage of effective therapies. Surgical removal is considered the most effective treatment for localised disease. ${ }^{3}$

Pancreatic cancer shows a multifactorial aetiology ${ }^{4}$ and the main epidemiological risk factors are tobacco smoking, heavy alcohol consumption, type 2 diabetes mellitus, obesity and chronic pancreatitis. ${ }^{5}$ Family history of pancreatic cancer is another risk factor, with about $5 \%-10 \%$ of patients reporting affected first-degree relatives, suggesting a contribution of inherited genetic variation in risk. ${ }^{6}$ As for other complex diseases, PDAC is affected both by rare highly penetrant mutations associated with high risk and common low-penetrance variants. Both genome-wide association studies (GWAS) and candidate gene studies have identified several SNPs associated with the risk of developing PDAC. ${ }^{7-17}$ Several SNPs with a genome-wide level of statistical significance $\left(\mathrm{p}<5 \times 10^{-8}\right)$ have been 
identified and many others are considered potentially interesting since they are very close to this threshold.

Moreover, many studies showed a connection between blood groups and the risk of several malignancies including pancreatic cancer, in particular increased risk for non-O blood group subjects. ${ }^{18-22}$

A viable approach to reduce PDAC mortality would be to implement early detection. The overall incidence of the disease is relatively low, thus screening is not suggested for the general population. It would therefore be useful to have tools to stratify the general population and to identify a subgroup at higher risk among whom a regular screening could bring benefits. Genetic variants can be useful for such risk stratification. Common variants, taken individually, are associated with a small increase in risk and therefore are not applicable for risk prediction. However, the combination of different SNPs increases the cumulative effect on risk. Thus, the establishment of a multigenic score could lead to a better estimation of individual risk. This approach has already been successfully attempted for other cancers such as prostate, ${ }^{23}$ breast $^{24-27}$ and endometrial. ${ }^{28}$ For pancreatic cancer a first attempt has been made, however it was based on a very small number of SNPs. ${ }^{29}$ The aim of this work was to generate a polygenic risk score (PRS) for PDAC risk prediction combining the effects of known risk SNPs, including the $A B O$ alleles. In addition, as an exploratory analysis, we have included two well-known risk factors, smoking and diabetes, to construct a multifactorial score.

\section{MATERIALS AND METHODS Study population}

The study was conducted on 3619 patients with PDAC and 5790 controls from nine European countries within the PANcreatic Disease ReseArch (PANDoRA) consortium. ${ }^{30}$ Cases were defined by an established diagnosis of PDAC and controls were individuals of the general population without a pancreatic disease at recruitment, individuals that were hospitalised for non-tumour related causes, or blood donors. For each subject, information on country of origin, sex and age (age at diagnosis for cases and age at recruitment for controls) was also available. In addition, for a subset of individuals, smoking (expressed as ever (current+former)/never smokers) and diagnosis of type 2 diabetes (before the diagnosis of PDAC for the cases) were retrospectively collected. In accordance with the Declaration of Helsinki, written informed consent was obtained from each participant. Finally, we also used as a validation step genotyping data of 8769 PDAC cases and 7055 controls downloaded from the database of Genotypes and Phenotypes (dbGaP, https://www. ncbi.nlm.nih.gov/gap/) (study accession numbers phs000206. v5.p3 and phs000648.v1.p1; project reference number 12644). The genotyping data were obtained from previously published GWAS on PDAC risk: the Pancreatic Cancer Cohort Consortium (PanScan I-III) ${ }^{7-9}$ and the Pancreatic Cancer Case-Control Consortium (PanC4). ${ }^{10}$

\section{SNP selection}

In order to generate a PRS, we selected polymorphisms belonging to the chromosomal regions identified through previous studies to be associated with PDAC risk at genome-wide significance level $\left(\mathrm{p}<5 \times 10^{-8}, 18\right.$ SNPs) or close to that threshold $\left(\mathrm{p}<10^{-7}\right.$, 11 SNPs). In regions with multiple risk-associated SNPs, only SNPs not in high LD $\left(\mathrm{r}^{2}<0.7\right)$ were selected. The selection was made based on the lowest $\mathrm{p}$ value with PDAC risk reported in the original study.

\begin{tabular}{lccr}
\hline Table 1 & Description of the PANDoRA study population & \\
\hline Country & Cases & Controls & Total \\
\hline Czech Republic & 386 & 450 & 836 \\
Germany & 1375 & 1791 & 3166 \\
Greece & 239 & 192 & 431 \\
Hungary & 260 & 353 & 613 \\
Italy & 968 & 1681 & 2649 \\
Lithuania & 56 & 185 & 241 \\
The Netherlands & 117 & 164 & 281 \\
Poland & 107 & 333 & 440 \\
UK & 111 & 311 & 422 \\
Total & 3619 & 5460 & 9079 \\
Sex (\%) & & & \\
$\quad$ Male & 56.6 & 53.1 & 54.5 \\
$\quad$ Female & 43.4 & 46.9 & 45.5 \\
Median age & 64.3 & 56.0 & 59.6 \\
\hline PANDA. & &
\end{tabular}

PANDoRA, PANcreatic Disease ReseArch.

We also included SNPs necessary to infer the ABO blood groups from genotypes, in order to use the blood groups in the computation of the score. Namely, we selected rs505922, which discriminates $\mathrm{O}$ from non-O and $\mathrm{rs} 8176746$ that distinguishes between $A B O \mathrm{~A}$ and $\mathrm{B}$ alleles. ${ }^{18} 2122$ The combination of these two SNPs allows to reconstruct $\mathrm{ABO}$ blood groups. The final selection resulted in 30 SNPs as described in online supplementary table I.

\section{Genotyping}

Genotyping of the PANDoRA cases and controls was performed at German Cancer Research Center in Heidelberg, Germany, using TaqMan or KASP (Kompetitive Allele-Specific PCR) technology, according to the manufacturer protocol, in 384-well plates. In addition to the samples, no-template controls and duplicated samples (8\%), used for quality control purposes, were included on each plate and genotyped under the same conditions. The endpoint fluorescence reading of the plates and the assignment of the genotype were performed using a ViiA 7 Real-Time PCR System (Thermo Fisher Applied Biosystems, Waltham, MA, USA).

\section{Data filtering, statistical analysis and score computation}

For PANDoRA we started from a total of 9409 subjects (3619 cases and 5790 controls). Pearson $\chi^{2}$ test was used to verify that the genotype frequencies of the controls were in Hardy-Weinberg equilibrium (HWE). We eliminated one genotyping plate filled with 330 controls because it systematically showed a deviation from HWE, leaving 5460 controls. The breakdown of cases and controls by countries is shown in table 1 .

After exclusion of subjects with missing covariates and genotypes we used up to 2851 cases and 4810 controls to test whether the associations of the single risk variants replicated. The samples used had an average call rate of $97.6 \%$, and a concordance rate between duplicated samples higher than $99 \%$.

Considering only samples with call rate of 100\%, 2879 subjects (839 cases and 2040 controls) remained for the PRS in PANDoRA, consisting of the 30 variants ( 28 loci each identified by an individual SNP and two SNPs for the ABO locus, see below).

For the PanScan I-III and PanC4 data sets obtained from dbGaP, genotyping procedures, genotyping quality control checks and data collection were thoroughly reported in the 
Table 2 Association between the selected SNPs and PDAC risk in PANDoRA

\begin{tabular}{|c|c|c|c|c|c|c|c|c|c|}
\hline \multirow[b]{3}{*}{ SNP } & \multirow[b]{3}{*}{ Nearest gene(s) } & \multirow{3}{*}{$\begin{array}{l}\text { Alleles } \\
(\mathrm{M} / \mathrm{m})\end{array}$} & \multicolumn{4}{|l|}{ Codominant model } & \multirow[b]{3}{*}{$P$ trend } & \multirow{2}{*}{\multicolumn{2}{|c|}{$\begin{array}{l}\text { Allelic model } \\
\text { M versus } \mathrm{m}\end{array}$}} \\
\hline & & & \multicolumn{2}{|l|}{$\mathrm{M} / \mathrm{M}$ versus $\mathrm{M} / \mathrm{m}$} & \multicolumn{2}{|l|}{$\mathrm{M} / \mathrm{M}$ versus $\mathrm{m} / \mathrm{m}$} & & & \\
\hline & & & OR $(95 \% \mathrm{Cl})$ & $P$ value & OR $(95 \% \mathrm{Cl})$ & $P$ value & & OR $(95 \% \mathrm{Cl})$ & $P$ value \\
\hline rs351365 & WNT2B & $\mathrm{G} / \mathrm{A}$ & 0.97 (0.87 to 1.08$)$ & 0.523 & 0.83 (0.66 to 1.04$)$ & 0.099 & 0.072 & $0.92(0.84$ to 1.00$)$ & 0.056 \\
\hline rs2816938 & NR5A2 & $T / A$ & 1.11 (0.99 to 1.24$)$ & 0.077 & 1.08 (0.86 to 1.36$)$ & 0.515 & 0.151 & 1.09 (0.99 to 1.19$)$ & 0.076 \\
\hline rs3790844 & NR5A2 & $\mathrm{T} / \mathrm{C}$ & 0.93 (0.83 to 1.05$)$ & 0.226 & 0.94 (0.74 to 1.19$)$ & 0.607 & 0.049 & 0.93 (0.84 to 1.02$)$ & 0.1 \\
\hline rs 2736100 & CLPTM1L TERT & $\mathrm{G} / \mathrm{T}$ & $0.97(0.86$ to 1.09$)$ & 0.614 & 1.21 (1.05 to 1.39$)$ & 0.008 & 0.012 & 1.09 (1.01 to 1.17$)$ & 0.018 \\
\hline rs2853677 & CLPTM1L TERT & $A / G$ & 0.78 (0.69 to 0.87$)$ & $2.47 \times 10^{-5}$ & 0.77 (0.66 to 0.89$)$ & $6.3 \times 10^{-4}$ & $2.5 \times 10^{-4}$ & 0.85 (0.79 to 0.92$)$ & $9.1 \times 10^{-5}$ \\
\hline rs2736098 & CLPTM1L TERT & $\mathrm{G} / \mathrm{A}$ & $0.90(0.81$ to 1.00$)$ & 0.050 & 0.85 (0.69 to 1.05$)$ & 0.123 & 0.004 & 0.85 (0.78 to 0.93$)$ & $3.6 \times 10^{-4}$ \\
\hline rs35226131 & CLPTM1L TERT & $\mathrm{G} / \mathrm{A}$ & 0.81 (0.64 to 1.03$)$ & 0.085 & 0.41 (0.12 to 1.34$)$ & 0.139 & 0.012 & 0.89 (0.71 to 1.11$)$ & 0.296 \\
\hline rs401681 & CLPTM1L TERT & $\mathrm{C} / \mathrm{T}$ & 1.20 (1.07 to 1.35$)$ & 0.002 & 1.31 (1.14 to 1.50$)$ & $1.3 \times 10^{-4}$ & $5.1 \times 10^{-6}$ & 1.14 (1.07 to 1.23$)$ & $1.7 \times 10^{-4}$ \\
\hline rs172310 & SHH & $\mathrm{C} / \mathrm{A}$ & 1.02 (0.92 to 1.14$)$ & 0.636 & 0.94 (0.78 to 1.12 ) & 0.462 & 0.964 & 1.01 (0.93 to 1.09 ) & 0.848 \\
\hline rs2941471 & HNF4G & $\mathrm{A} / \mathrm{G}$ & 0.95 (0.84 to 1.07$)$ & 0.396 & 0.79 (0.68 to 0.92$)$ & 0.003 & 0.013 & $0.89(0.82$ to 0.96$)$ & 0.004 \\
\hline rs10094872 & MYC & $\mathrm{A} / \mathrm{T}$ & 1.16 (1.03 to 1.29$)$ & 0.011 & 1.40 (1.20 to 1.64$)$ & $2.6 \times 10^{-5}$ & $2.9 \times 10^{-5}$ & 1.18 (1.09 to 1.28$)$ & $2.4 \times 10^{-5}$ \\
\hline rs1561927 & MIR1208 & $\mathrm{T} / \mathrm{C}$ & $0.83(0.75$ to 0.93$)$ & 0.001 & 0.81 (0.66 to 1.00$)$ & 0.044 & $3.4 \times 10^{-4}$ & 0.86 (0.79 to 0.94$)$ & 0.001 \\
\hline rs8176746 & $A B O$ & $C / A$ & $1.10(0.96$ to 1.26$)$ & 0.171 & 1.11 (0.68 to 1.80$)$ & 0.674 & 0.235 & 1.04 (0.92 to 1.17$)$ & 0.546 \\
\hline rs505922 & $A B O$ & $\mathrm{~T} / \mathrm{C}$ & 1.39 (1.24 to 1.55$)$ & $7.2 \times 10^{-9}$ & 1.39 (1.20 to 1.61$)$ & $1.6 \times 10^{-5}$ & $1.4 \times 10^{-7}$ & 1.19 (1.10 to 1.28$)$ & $4.0 \times 10^{-6}$ \\
\hline rs10991043 & SMC2 & $\mathrm{T} / \mathrm{C}$ & 1.05 (0.94 to 1.17$)$ & 0.403 & 1.02 (0.87 to 1.19$)$ & 0.793 & 0.353 & 1.01 (0.94 to 1.09$)$ & 0.709 \\
\hline rs7310409 & HNF1A & $\mathrm{G} / \mathrm{A}$ & 1.02 (0.91 to 1.14$)$ & 0.709 & $1.21(1.05$ to 1.40$)$ & 0.010 & 0.051 & 1.08 (1.01 to 1.16$)$ & 0.033 \\
\hline rs9581943 & PDX1 & $\mathrm{G} / \mathrm{A}$ & 0.95 (0.85 to 1.07$)$ & 0.431 & 1.17 (1.01 to 1.36$)$ & 0.043 & 0.052 & 1.07 (0.99 to 1.16$)$ & 0.092 \\
\hline rs9543325 & $13 q 22.1$ & $\mathrm{~T} / \mathrm{C}$ & 1.18 (1.05 to 1.32$)$ & 0.005 & $1.43(1.23$ to 1.66$)$ & $3.2 \times 10^{-6}$ & $4.1 \times 10^{-6}$ & 1.18 (1.10 to 1.28$)$ & $1.3 \times 10^{-5}$ \\
\hline rs8028529 & $15 q 14$ & $\mathrm{~T} / \mathrm{C}$ & 1.00 (0.90 to 1.11$)$ & 0.966 & $1.15(0.92$ to 1.45$)$ & 0.229 & 0.907 & 1.05 (0.96 to 1.15$)$ & 0.291 \\
\hline
\end{tabular}

All analyses were adjusted for age, sex and geographic region of origin.

Text in bold indicates associations with $p \leq 0.05$.

m, minor allele; M, major allele; PANDoRA, PANcreatic Disease ReseArch; PDAC, pancreatic ductal adenocarcinoma.

original publications. ${ }^{7-10}$ We removed individuals with gender mismatches, call rate $<0.9$, minimal or excessive heterozygosity ( $>3$ SDs from the mean) or cryptic relatedness (PI_HAT $>0.2$ ). We performed imputation using IMPUTE $4^{31}$ and the 1000 Genomes version 3 reference panel. ${ }^{32}$ The different GWAS data sets were each imputed separately. We discarded SNPs with a minor allele frequency $<0.5 \%$, completion rate $<90 \%$, evidence for violations of HWE $\left(\mathrm{p}<10^{-6}\right)$ or low-quality imputation score (INFO score $<0.7$ ). The number of SNPs available in the final data set was 7509345. Principal component analysis was carried out including genotypes from all the populations of phase 3 of the 1000 Genomes Project (http://www.internationalgenome. org/). Individuals not clustering with the 1000 Genomes subjects of European descent were excluded from further analysis.

Unconditional logistic regression was used to validate the associations between the individual SNPs and PDAC risk. ORs, 95\% CIs and $\mathrm{p}$ values were calculated. The SNPs were analysed according to the codominant and allelic inheritance models,

Table 3 Association between the ABO blood groups and PDAC risk in 2361 PDAC cases and 4418 controls from PANDoRA

\begin{tabular}{|c|c|c|c|c|c|c|}
\hline Cases & Controls & rs505922 & rs8176746 & Blood group & OR $(95 \% \mathrm{Cl})$ & $P$ value \\
\hline 780 & 1785 & $T / T$ & Any & 00 & Reference & - \\
\hline 885 & 1474 & $\mathrm{~T} / \mathrm{C}$ & $\mathrm{C} / \mathrm{C}$ & AO & 1.40 (1.24 to 1.59$)$ & $6.41 \times 10^{-8}$ \\
\hline 242 & 370 & $\mathrm{C} / \mathrm{C}$ & $\mathrm{C} / \mathrm{C}$ & AA & 1.53 (1.27 to 1.85$)$ & $1.09 \times 10^{-5}$ \\
\hline 281 & 481 & $\mathrm{~T} / \mathrm{C}$ & $\mathrm{A} / \mathrm{A}$ & BO & 1.40 (1.18 to 1.67$)$ & $1.70 \times 10^{-4}$ \\
\hline 27 & 52 & $\mathrm{C} / \mathrm{C}$ & $\mathrm{A} / \mathrm{A}$ & BB & 1.34 (0.82 to 2.20$)$ & 0.245 \\
\hline 146 & 256 & $\mathrm{~T} / \mathrm{C}$ or $\mathrm{C} / \mathrm{C}$ & $\mathrm{C} / \mathrm{A}$ & $A B$ & 1.27 (0.82 to 2.20$)$ & 0.042 \\
\hline
\end{tabular}

All analyses were adjusted for age, sex and geographic region of origin.

Text in bold indicates associations with $\mathrm{p} \leq 0.05$.

PANDoRA, PANcreatic Disease ReseArch; PDAC, pancreatic ductal adenocarcinoma. 
Table 4 Associations between the genetic scores and PDAC risk

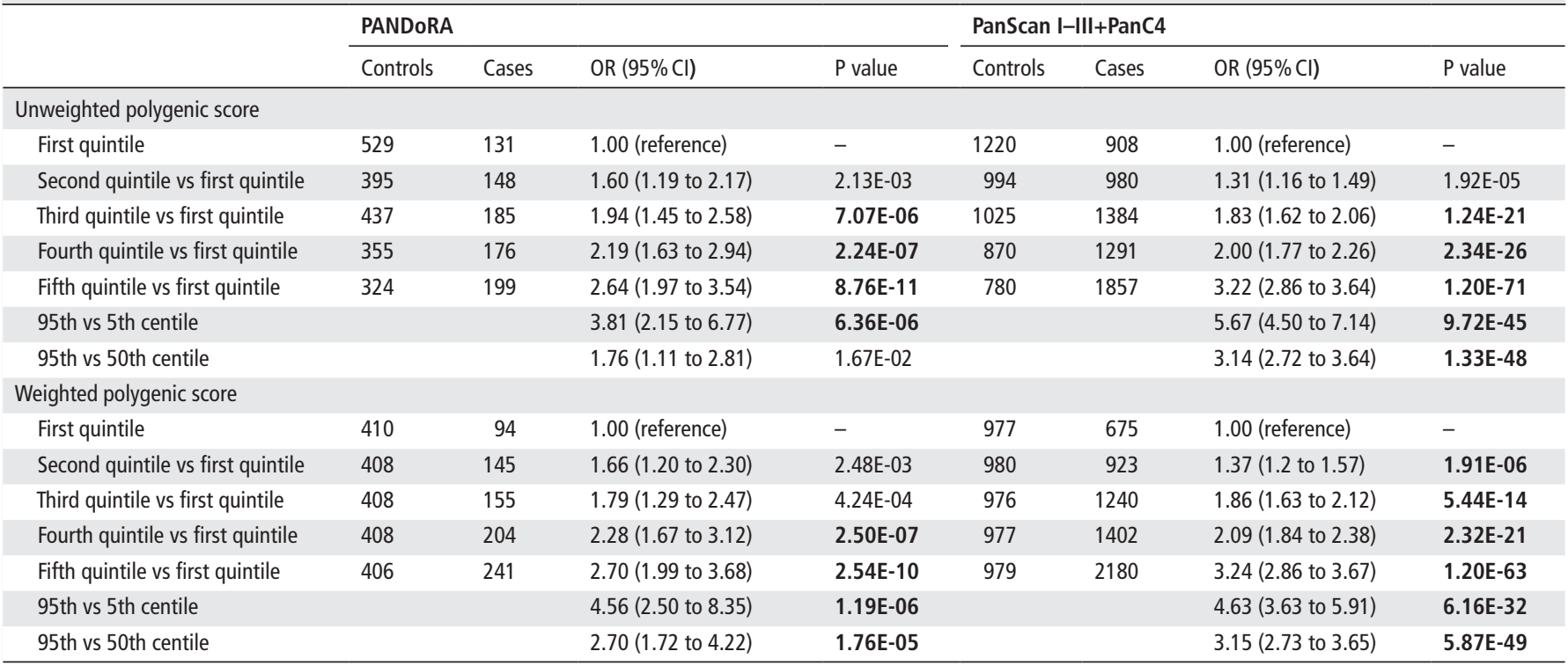

All analyses were adjusted for age, sex and geographic region of origin (PANDoRA) or the top eight principal components (PanScan I-III+PanC4).

Text in bold indicates associations with $\mathrm{p} \leq 0.05$.

PanC4, Pancreatic Cancer Case-Control Consortium; PANDoRA, PANcreatic Disease ReseArch; PanScan, Pancreatic Cancer Cohort Consortium; PDAC, pancreatic ductal adenocarcinoma.

using the most common allele in controls as reference. The association between genotype-derived ABO blood groups and PDAC risk was also tested with unconditional logistic regression using the $\mathrm{O}$ group as the reference category. To validate the associations between the risk factors assessed as dichotomous variables and PDAC risk, logistic regression was used. All analyses were adjusted for: sex, age and country of origin (PANDoRA) or sex, age and the top eight principal components (PanScan and PanC4). Associations showing a p value less than 0.05 were considered significant since all these associations have been extensively studied and replicated elsewhere.

The genetic score was computed on the subset of subjects that had $100 \%$ call rate, consisting of 839 cases and 2040 controls in PANDoRA and 6420 cases and 4889 controls in PanScan I-III and PanC4, for a total of 14188 subjects. Score quintiles were calculated based on their distribution in the controls. Details on score computation have been give elsewhere ${ }^{14}$ and in the online supplementary material.

We built two types of PRS, a simple unweighted score and a weighted score. We generated the unweighted score for each subject by summing the total number of risk alleles (attributing the value of 1 to each risk allele) and adding the value associated with the $\mathrm{ABO}$ groups, with a value of 0 for the $\mathrm{OO}$ group, 1 for $\mathrm{OA} / \mathrm{OB}$ and 2 for $\mathrm{AB}$ group. We generated the weighted score assigning to each genotype the relative OR, using the OR reported in the literature by GWAS on PDAC, and the same was done for the $\mathrm{ABO}$ groups. Subsequently, from the product of all the ORs, we obtained the weighted score of each individual. Online supplementary table II shows an example of how the scores were generated. The computed score was used as a categorical variable, calculating the quintiles based on the distribution in controls. We validated the genetic scores in 6420 PDAC cases and 4889 controls (subjects from PanScan I-III and PanC4 with $100 \%$ call rate) using the same statistical models used for the PANDoRA data set and adjusting for the top eight principal components to avoid confounding due to population stratification.
We also computed multifactorial scores (for PANDoRA only) complementing the genetic weighted score with variables for tobacco smoking and type 2 diabetes, using 101 PDAC cases and 250 controls. The computed scores were analysed for their association with PDAC risk with logistic regression, adjusting for sex, age and country of origin. Given the limited number of subjects in PANDoRA who had 100\% call rate and complete data for the covariates, we also included in the multifactorial score subjects without all the genetic variants (call rate $>80 \%$, 243 cases and 511 controls) and normalised the scores of each subject, in order to make them comparable, by multiplying them for (total number of variables)/(number of available variables) obtaining a 'scaled' score.

Receiver operating characteristic curves were constructed and the related areas under the curve (AUC) were calculated, to determine the performance of scores in discriminating individuals with the disease from individuals without the disease.

\section{RESULTS}

\section{Main effects of SNPs, ABO blood groups and epidemiological risk factors}

Most of the associations between the GWAS-identified SNPs and ABO blood groups and PDAC risk were replicated in PANDoRA, using up to 2851 cases and 4810 controls (tables 2 and 3 ).

As expected, we observed statistically significant associations between smoking (with 1472 cases and 1865 controls), diabetes (with 1028 cases and 1906 controls) and PDAC risk $(\mathrm{OR}=2.66$, $95 \%$ CI 2.20 to $3.21, \mathrm{p}=2 \times 10^{-22}$ for smoking, and $\mathrm{OR}=1.46$, $95 \%$ CI 1.14 to $1.86, \mathrm{p}=0.003$ for diabetes) (online supplementary table III).

\section{Risk scores}

The PRS (which includes the genetically predicted ABO blood groups) showed very significant associations. For the highest versus lowest quintile of the unweighted score we observed in PANDoRA an OR=2.64 (95\% CI 1.97 to $\left.3.54, \mathrm{p}=8.76 \times 10^{-11}\right)$ 
Table 5 Associations between scores with genetic and non-genetic variables and PDAC risk in PANDoRA

\begin{tabular}{|c|c|c|c|c|}
\hline Quintile & Controls & Cases & OR $(95 \% \mathrm{Cl})$ & $P$ value \\
\hline \multicolumn{5}{|c|}{ Unweighted multifactorial score } \\
\hline First quintile & 63 & 13 & 1.00 (reference) & - \\
\hline $\begin{array}{l}\text { Second quintile vs first } \\
\text { quintile }\end{array}$ & 50 & 12 & 1.09 (0.45 to 2.63$)$ & $8.53 \mathrm{E}-01$ \\
\hline $\begin{array}{l}\text { Third quintile vs first } \\
\text { quintile }\end{array}$ & 51 & 27 & 2.55 (1.19 to 5.47$)$ & $1.60 \mathrm{E}-02$ \\
\hline $\begin{array}{l}\text { Fourth quintile vs first } \\
\text { quintile }\end{array}$ & 47 & 17 & $1.70(0.75$ to 3.88$)$ & $2.05 \mathrm{E}-01$ \\
\hline $\begin{array}{l}\text { Fifth quintile vs first } \\
\text { quintile }\end{array}$ & 39 & 32 & 3.89 (1.81 to 8.37$)$ & 5.05E-04 \\
\hline \multicolumn{5}{|c|}{ Weighted multifactorial score } \\
\hline First quintile & 60 & 6 & 1.00 (reference) & \\
\hline $\begin{array}{l}\text { Second quintile vs first } \\
\text { quintile }\end{array}$ & 58 & 12 & 2.02 (0.71 to 5.75$)$ & $1.90 \mathrm{E}-01$ \\
\hline $\begin{array}{l}\text { Third quintile vs first } \\
\text { quintile }\end{array}$ & 51 & 13 & 2.54 (0.89 to 7.19$)$ & $8.00 \mathrm{E}-02$ \\
\hline $\begin{array}{l}\text { Fourth quintile vs first } \\
\text { quintile }\end{array}$ & 46 & 20 & 4.21 (1.55 to 11.4$)$ & $4.71 \mathrm{E}-03$ \\
\hline $\begin{array}{l}\text { Fifth quintile vs first } \\
\text { quintile }\end{array}$ & 35 & 50 & 14.37 (5.57 to 37.09$)$ & $3.64 \mathrm{E}-08$ \\
\hline
\end{tabular}

and for the highest versus lowest quintile of the weighted score, $\mathrm{OR}=2.70\left(95 \%\right.$ CI 1.99 to $\left.3.68, \mathrm{p}=2.54 \times 10^{-10}\right)$, using 839 cases and 2040 controls. The results are shown in table 4 . The validation analysis performed in the PanScan and PanC4 data sets, using 6420 cases and 4889 controls, showed similar results. For the unweighted score, we observed an $\mathrm{OR}=3.22(95 \% \mathrm{CI} 2.86$ to 3.64, $\mathrm{p}=1.20 \times 10^{-71}$ ) for the highest versus lowest quintile and $\mathrm{OR}=3.24\left(95 \% \mathrm{CI} 2.86\right.$ to $\left.3.67, \mathrm{p}=1.20 \times 10^{-63}\right)$ for the weighted score comparing the highest versus lowest quintile. When we restricted the analyses to the extreme tails of the distribution, we observed substantially larger risks, with good agreement between PANDoRA and the PanScan+PanC4 data set. Namely, when we compared the top versus the bottom $5 \%$ of the distributions. We observed $\mathrm{OR}=4.56\left(95 \% \mathrm{CI} 2.50\right.$ to $\left.8.35 . \mathrm{p}=1.19 \times 10^{-6}\right)$ in PANDoRA and OR $=4.63\left(95 \%\right.$ CI 3.63 to $\left.5.91, \mathrm{p}=6.16 \times 10^{-32}\right)$ in PanScan+PanC4. The results are shown in table 4.

The exploratory analysis of different multifactorial risk scores, using 101 PDAC cases and 250 controls, showed significant associations as well. The results are summarised in table 5 . The weighted score complemented with smoking and diabetes showed OR=14.37 (95\% CI 5.57 to $\left.37.09, p=3.64 \times 10^{-8}\right)$ for the highest versus lowest quintile. Similar statistically significant results were observed with the scaled score $(\mathrm{OR}=6.01,95 \% \mathrm{CI}$ 3.48 to $10.39, p=1.28 \times 10^{-10}$ ), which includes a larger number of individuals (243 cases and 511 controls). The results of the scaled score are reported in table 6.

\section{Evaluation of prediction performance results}

The AUC value for the unweighted PRS is 0.59 (95\% CI 0.57 to 0.61 ) in PANDoRA and 0.61 (95\% CI 0.60 to 0.63 ) in the PanScan I-III and PanC4 combined data set. The highest AUC value for the multifactorial scores is 0.63 (95\% CI 0.59 to 0.67$)$.

\section{DISCUSSION}

A promising way to decrease PDAC mortality is to improve early detection, which can be achieved by identifying subjects at high
Table 6 Associations between scores scaled (call rate $>80 \%$ ) with genetic and non-genetic variables and PDAC risk in PANDoRA

\begin{tabular}{|c|c|c|c|c|}
\hline Quintile & Controls & Cases & OR $(95 \% \mathrm{Cl})$ & $P$ value \\
\hline \multicolumn{5}{|c|}{ Unweighted multifactorial score } \\
\hline First quintile & 113 & 29 & 1.00 (reference) & - \\
\hline $\begin{array}{l}\text { Second quintile vs first } \\
\text { quintile }\end{array}$ & 116 & 41 & $1.17(0.65$ to 2.11$)$ & $5.91 \mathrm{E}-01$ \\
\hline $\begin{array}{l}\text { Third quintile vs first } \\
\text { quintile }\end{array}$ & 116 & 62 & 2.17 (1.25 to 3.76$)$ & $5.96 \mathrm{E}-03$ \\
\hline $\begin{array}{l}\text { Fourth quintile vs first } \\
\text { quintile }\end{array}$ & 79 & 29 & 1.34 (0.71 to 2.54$)$ & $3.63 \mathrm{E}-01$ \\
\hline $\begin{array}{l}\text { Fifth quintile vs first } \\
\text { quintile }\end{array}$ & 87 & 82 & $3.66(2.11$ to 6.33$)$ & $3.62 \mathrm{E}-06$ \\
\hline \multicolumn{5}{|c|}{ Weighted multifactorial score } \\
\hline First quintile & 116 & 38 & 1.00 (reference) & - \\
\hline $\begin{array}{l}\text { Second quintile vs first } \\
\text { quintile }\end{array}$ & 121 & 35 & $0.83(0.46$ to 1.50$)$ & 5.43E-01 \\
\hline $\begin{array}{l}\text { Third quintile vs first } \\
\text { quintile }\end{array}$ & 98 & 48 & 1.75 (0.99 to 3.10$)$ & $5.40 \mathrm{E}-02$ \\
\hline $\begin{array}{l}\text { Fourth quintile vs first } \\
\text { quintile }\end{array}$ & 100 & 35 & $1.10(0.61$ to 2.00$)$ & $7.50 \mathrm{E}-01$ \\
\hline $\begin{array}{l}\text { Fifth quintile vs first } \\
\text { quintile }\end{array}$ & 76 & 87 & 6.01 (3.48 to 10.39$)$ & $1.28 \mathrm{E}-10$ \\
\hline
\end{tabular}

Scaled scores obtained by multiplying the score for (total number of variables)/ (number of available variables), in subjects with call rate $>80 \%$. All analyses were adjusted for age, sex and geographic region of origin.

Text in bold indicates associations with $\mathrm{p} \leq 0.05$.

PANDoRA, PANcreatic Disease ReseArch; PDAC, pancreatic ductal adenocarcinoma.

risk of developing the disease. The International Cancer of the Pancreas Screening consortium recommends regular screening for subjects with at least a fivefold increased risk. ${ }^{33}$ This level of risk determination can be obtained by integrating genetic and epidemiological risk factors. In recent years a number of SNPs convincingly associated with PDAC risk have been reported..$^{7-13}$ They generally show a small effect on risk $(\mathrm{OR}<1.5)$, therefore individually are not very useful in risk prediction. Yet, combining them in a PRS may lead to a significant improvement in risk prediction, ${ }^{3435}$ as already demonstrated for other diseases. ${ }^{36-38}$

The PRS reached high statistical significance both when unweighted and weighted, with similar ORs in PANDoRA and in the combined PanScan I-III+PanC4 data set, with an approximately threefold increase in risk for the $20 \%$ of subjects with the highest score values if compared with the subjects with the $20 \%$ lowest. The level of risk becomes more pronounced when looking only at the extremes of the distribution, with approximately fivefold differences in risk between the top and the bottom $5 \%$. This level of risk is in the same order of magnitude as reported for rare, highly penetrant mutations in familial pancreatic cancer syndromes (eg, for mutations in BRCA1, BRCA2 or ATM). ${ }^{4}$ The substantial concordance between PANDoRA and the combined PanScan I-III+PanC4 data set, based on data of about 7000 PDAC cases and 7000 controls, makes us confident in the stability of these predictions.

In spite of the clear discrimination of risk level and the strong statistical significance, the values of the AUC based on the SNPs alone (ranging from 0.59 to 0.61 ) are not satisfactory. However, theoretical predictions ${ }^{39}$ and previous studies on cancer types for which a much larger number of risk SNPs are known ${ }^{23243637}$ have shown that the addition of risk variants increases the predictive power of PRS, to the point of envisaging their implementation in screening of the general population. ${ }^{25}$ Thus, it is foreseeable that continued efforts for discovery of novel pancreatic cancer 
risk SNPs will enable us in the middle/long term to build scores with a much larger number of genetic variants, which will lead to much improved risk prediction.

Furthermore, it is useful to combine the genetic score with non-genetic risk factors obtaining a multifactorial score. This has already been done for other cancers and has shown slightly better prediction performances. ${ }^{23} 3740$ The idea is to build a score that includes all known genetic variants associated with risk and all known epidemiological risk factors. The exploratory results we observed in our data set are encouraging because they showed a large increase in the ORs. It should, however, be noted that the data of the covariates in PANDoRA are largely incomplete and currently this prevents us from including all known non-genetic risk factors in the score. Moreover, as retrospective data, they may be subjected to recall bias. Data available from dbGaP for PanScan I-III and PanC4 do not include any variable about known risk factors; thus we could not evaluate the multifactorial score in the replication data set. For these reasons, we need to use caution in interpreting the results, but the combination of genotypes and data on risk factors seems a suitable way for the construction of a score that leads to the identification of a subgroup of subjects with very high risk. Indeed, subjects in the highest quintile of the multifactorial score including both smoking and diabetes reached an $\mathrm{OR}=14.37$, which is comparable to effect of rare high-penetrance disease causing mutations.

Strengths of this study are the sample size, since it is the largest study of this type conducted on PDAC to date, and the number of polymorphisms included in the computation of the genetic score, since all the known loci have been included in the score, unlike what was previously done. In addition, another clear advantage of this study is the external validation of the score using PanScan and PanC4 data. The limitations are the possible bias deriving from the inclusion of subjects that come from different countries and the fact that in PANDoRA the information on epidemiological and lifestyle factors is limited. In addition, it is possible that the OR that we observe in the multifactorial risk score is inflated, given the relatively small sample size (101 cases and 250 controls) that we could use for running that exploratory analysis.

In conclusion, in this study, we found a highly significant association between a PRS and the risk of PDAC onset, which explains more than individual SNPs and is a step forward in the direction of the construction of a tool for risk stratification. Furthermore, the exploratory analysis of a multifactorial score was encouraging. In perspective, the implementation of the score with new genetic risk variants, which are continuously discovered, and with complete data on epidemiological risk factors can lead to the achievement of a tool for risk stratification of clinical utility. Such an instrument, if perfected, could be conceived as a tool for risk stratification in the population, which in turn can contribute to improved early diagnosis. A test with relatively low predictive power as the score could be used to define groups of subjects at increased risk on which to apply screening tools and, lastly, the expensive and invasive imaging on the subjects that are positive.

\footnotetext{
Author affiliations

${ }^{1}$ Department of Biology, University of Pisa, Pisa, Italy

${ }^{2}$ Genomic Epidemiology Group, German Cancer Research Center (DKFZ), Heidelberg, Germany

${ }^{3}$ Department of Translational Research and New Technologies in Medicine and Surgery, University of Pisa, Pisa, Italy

${ }^{4}$ Department of General, Visceral and Transplantation Surgery, University of Heidelberg, Heidelberg, Germany

${ }^{5}$ Pancreatic and Endocrine Surgical Unit, University of Padova, Padova, Italy
}

${ }^{6}$ Department of General, Visceral and Thoracic Surgery, University Medical Center Hamburg-Eppendorf, Hamburg, Germany

${ }^{7}$ Gastroenterology and Gastrointestinal Endoscopy Unit, Vita-Salute San Raffaele University, San Raffaele Scientific Institute, Milano, Italy

${ }^{8}$ Department of Gastroenterology, Polyclinic of Sant'Orsola, Bologna, Italy

${ }^{9}$ Institute for Health Research, Liverpool Pancreas Biomedical Research Unit,

University of Liverpool, Liverpool, UK

${ }^{10}$ Saarland Cancer Registry, Saarbrücken, Germany

${ }^{11}$ Division of Clinical Epidemiology and Aging Research, German Cancer Research

Center (DKFZ), Heidelberg, Germany

${ }^{12}$ Network Aging Research, University of Heidelberg, Heidelberg, Germany

${ }^{13}$ Department of Gastroenterology and Institute for Digestive Research, Lithuanian

University of Health Sciences, Kaunas, Lithuania

${ }^{14}$ Oncological Department, Azienda USL Toscana Nord Ovest, Oncological Unit of

Massa Carrara, Carrara, Italy

${ }^{15}$ Cancer Epidemiology Unit, Nuffield Department of Population Health, University of

Oxford, Oxford, UK

${ }^{16}$ Institute for Translational Medicine, Medical School, University of Pécs, Pécs,

Hungary

${ }^{17}$ First Department of Medicine, University of Szeged, Szeged, Hungary

${ }^{18}$ Digestive and Liver Disease Unit, S. Andrea Hospital, S. Andrea Hospital 'Sapienza' University of Rome, Rome, Italy

${ }^{19}$ Pancreato-Biliary Endoscopy and EUS Division, Pancreas Translational and Clinical Research Center, San Raffaele Scientific Institute IRCCS, Milano, Italy

${ }^{20}$ Department of Laboratory Medicine, University-Hospital of Padova, Padova, Italy

${ }^{21}$ Third Surgical Clinic - Department of Surgery, Oncology and Gastroenterology

(DiSCOG), University of Padua, Padova, Italy

${ }^{22}$ Laboratory for Experimental Oncology and Radiobiology Center for Experimental and Molecular Medicine, Amsterdam UMC, University of Amsterdam, Amsterdam,

The Netherlands

${ }^{23}$ Cancer Center Amsterdam, Amsterdam, The Netherlands

${ }^{24}$ Division of Gastroenterology and Research Laboratory, Department of Oncology,

Fondazione IRCCS Casa Sollievo della Sofferenza, San Giovanni Rotondo, Italy

${ }^{25}$ Biomedical Center, Faculty of Medicine in Pilsen, Charles University, Pilsen, Czech

Republic

${ }^{26}$ Department of Digestive Tract Diseases, Medical University of Lodz, Lodz, Poland

${ }^{27}$ Department of Oncology, Faculty of Medicine and Dentistry, Palacky University

Olomouc and University Hospital Olomouc, Olomouc, Czech Republic

${ }^{28}$ Institute of Molecular and Translational Medicine, Faculty of Medicine and

Dentistry, Palacky University Olomouc, Olomouc, Czech Republic

${ }^{29}$ Department of Medical Oncology, Amsterdam UMC, University of Amsterdam,

Amsterdam, The Netherlands

${ }^{30}$ Department of Surgery I, Faculty of Medicine and Dentistry, Palacky University

Olomouc and University Hospital Olomouc, Olomouc, Czech Republic

${ }^{31}$ Department of Surgical Oncology and HPB Surgery, University of Cyprus, Nicosia,

Cyprus

${ }^{32}$ Szent György University Teaching Hospital of Fejér County, Székesfehérvár, Hungary

${ }^{33}$ First Propaedeutic University Surgery Clinic, Hippocratio General Hospital, Medical School, National and Kapodistrian University of Athens, Athens, Greece

${ }^{34}$ Department of Hematology, Institute of Hematology and Transfusion Medicine,

Warsaw, Poland

${ }^{35}$ Division of Cancer Epidemiology, German Cancer Research Center (DKFZ),

Heidelberg, Germany

${ }^{36}$ Second Department of Internal Medicine and Research Unit, "Attikon" University General Hospital, Medical School, National and Kapodistrian University of Athens,

Athens, Greece

${ }^{37}$ Department of Interventional Gastroenterology, National Institute of Oncology,

Budapest, Hungary

${ }^{38}$ Division of General and Transplant Surgery, Pisa University Hospital, Pisa, Italy

${ }^{39}$ Laboratory of Biology, Medical School, National and Kapodistrian University of

Athens, Athens, Greece

${ }^{40}$ Department of Molecular Biology of Cancer, Institute of Experimental Medicine of the Czech Academy of Sciences, Prague, Czech Republic

${ }^{41}$ Institute of Biology and Medical Genetics, First Faculty of Medicine, Charles University, Prague, Czech Republic

${ }^{42}$ Biomedical Centre, Faculty of Medicine in Pilsen, Charles University, Pilsen, Czech Republic

${ }^{43}$ Division of Preventive Oncology, German Cancer Research Center (DKFZ) and National Center for Tumor Diseases (NCT), Heidelberg, Germany

${ }^{44}$ German Cancer Consortium (DKTK), German Cancer Research Center (DKFZ)

Heidelberg, Heidelberg, Germany

${ }^{45}$ General and Pancreatic Surgery Department, Pancreas Institute, University of Verona, Verona, Italy

Acknowledgements The authors thank Tom van Leusden and Cynthia Waasdorp for technical support (Amsterdam UMC). 
Contributors $D C$ and FC conceived the study. MG, CR and AAG performed experimental work. DC, MG and AAG performed data analysis. All other authors contributed to the collection of samples and data. MG, AAG, CR, DC and FC drafted the manuscript, and all other authors took part in its critical revision. FC and DC share last authorship.

Funding This work was partially supported by Fondazione Arpa (www. fondazionearpa.it) and by Fondazione Tizzi (www.fondazionetizzi.it).

Competing interests MFB has received research funding from Celgene. HvL has acted as a consultant for Celgene, and Eli Lilly and Company, Nordic Pharma Group and Philips, and has received research grants from Amgen, Bayer Schering Pharma, Celgene, Eli Lilly and Company, GlaxoSmithKline Pharmaceuticals, MSD, Nordic Pharma Group, Philips and Roche Pharmaceuticals.

\section{Patient consent for publication Not required.}

Ethics approval The PANDoRA study protocol was approved by the Ethics Commission of the Medical Faculty of the University of Heidelberg.

Provenance and peer review Not commissioned; externally peer reviewed.

Data availability statement Data are available upon reasonable request. Data may be obtained from a third party and are not publicly available. The data supporting the findings of this study are available upon reasonable request from the corresponding author. The data are not publicly available due to privacy or ethical restrictions. Sharing data will be conditional to approval by the PANDoRA steering committee and, if needed, to additional approval of the competent Institutional Review Boards.

\section{ORCID iDs}

Manuel Gentiluomo http://orcid.org/0000-0002-0366-9653

Orazio Palmieri http://orcid.org/0000-0002-0019-7929

Maria Gazouli http://orcid.org/0000-0002-3295-6811

\section{REFERENCES}

1 Kleeff J, Korc M, Apte M, La Vecchia C, Johnson CD, Biankin AV, Neale RE, Tempero M, Tuveson DA, Hruban RH, Neoptolemos JP. Pancreatic cancer. Nat Rev Dis Primers 2016;2:16022

2 Becker AE, Hernandez YG, Frucht H, Lucas AL. Pancreatic ductal adenocarcinoma: risk factors, screening, and early detection. World J Gastroenterol 2014;20:11182-98.

3 Ryan DP, Hong TS, Bardeesy N. Pancreatic adenocarcinoma. N Engl J Med 2014;371:1039-49.

4 Amundadottir LT. Pancreatic cancer genetics. Int J Biol Sci 2016;12:314-25.

5 Maisonneuve $P$, Lowenfels $A B$. Risk factors for pancreatic cancer: a summary review of meta-analytical studies. Int J Epidemiol 2015;44:186-98.

6 Klein AP. Genetic susceptibility to pancreatic cancer. Mol Carcinog 2012;51:14-24

7 Amundadottir L, Kraft P, Stolzenberg-Solomon RZ, Fuchs CS, Petersen GM, Arslan AA, Bueno-de-Mesquita HB, Gross M, Helzlsouer K, Jacobs EJ, LaCroix A, Zheng W, Albanes D, Bamlet W, Berg CD, Berrino F, Bingham S, Buring JE, Bracci PM, Canzian F, Clavel-Chapelon F, Clipp S, Cotterchio M, de Andrade M, Duell EJ, Fox JW, Gallinger S, Gaziano JM, Giovannucci EL, Goggins M, González CA, Hallmans G, Hankinson SE, Hassan M, Holly EA, Hunter DJ, Hutchinson A, Jackson R, Jacobs KB, Jenab M, Kaaks R, Klein AP, Kooperberg C, Kurtz RC, Li D, Lynch SM, Mandelson M, McWilliams RR, Mendelsohn JB, Michaud DS, Olson SH, Overvad K, Patel AV, Peeters PHM, Rajkovic A, Riboli E, Risch HA, Shu X-O, Thomas G, Tobias GS, Trichopoulos D, Van Den Eeden SK, Virtamo J, Wactawski-Wende J, Wolpin BM, Yu H, Yu K, Zeleniuch-Jacquotte A, Chanock SJ, Hartge P, Hoover RN. Genome-wide association study identifies variants in the ABO locus associated with susceptibility to pancreatic cancer. Nat Genet 2009;41:986-90.

8 Petersen GM, Amundadottir L, Fuchs CS, Kraft P, Stolzenberg-Solomon RZ, Jacobs KB, Arslan AA, Bueno-de-Mesquita HB, Gallinger S, Gross M, Helzlsouer K, Holly EA Jacobs EJ, Klein AP, LaCroix A, Li D, Mandelson MT, Olson SH, Risch HA, Zheng W, Albanes D, Bamlet WR, Berg CD, Boutron-Ruault M-C, Buring JE, Bracci PM, Canzian F, Clipp S, Cotterchio M, de Andrade M, Duell EJ, Gaziano JM, Giovannucci EL, Goggins M, Hallmans G, Hankinson SE, Hassan M, Howard B, Hunter DJ, Hutchinson A, Jenab M, Kaaks R, Kooperberg C, Krogh V, Kurtz RC, Lynch SM, McWilliams RR, Mendelsohn JB, Michaud DS, Parikh H, Patel AV, Peeters PHM, Rajkovic A, Riboli E, Rodriguez L, Seminara D, Shu X-O, Thomas G, Tjønneland A, Tobias GS, Trichopoulos D, Van Den Eeden SK, Virtamo J, Wactawski-Wende J, Wang Z, Wolpin BM, Yu H, Yu K, Zeleniuch-Jacquotte A, Fraumeni JF, Hoover RN, Hartge P, Chanock SJ. A genome-wide association study identifies pancreatic cancer susceptibility loci on chromosomes 13q22.1, 1q32.1 and 5p15.33. Nat Genet 2010;42:224-8.

9 Wolpin BM, Rizzato C, Kraft P, Kooperberg C, Petersen GM, Wang Z, Arslan AA, Beane-Freeman L, Bracci PM, Buring J, Canzian F, Duell EJ, Gallinger S, Giles GG, Goodman GE, Goodman PJ, Jacobs EJ, Kamineni A, Klein AP, Kolonel LN, Kulke MH, Li D, Malats N, Olson SH, Risch HA, Sesso HD, Visvanathan K, White E, Zheng W, Abnet CC, Albanes D, Andreotti G, Austin MA, Barfield R, Basso D, Berndt SI, Boutron-Ruault M-C, Brotzman M, Büchler MW, Bueno-de-Mesquita HB, Bugert $\mathrm{P}$, Burdette L, Campa D, Caporaso NE, Capurso G, Chung C, Cotterchio M, Costello E, Elena J, Funel N,
Gaziano JM, Giese NA, Giovannucci EL, Goggins M, Gorman MJ, Gross M, Haiman CA, Hassan M, Helzlsouer KJ, Henderson BE, Holly EA, Hu N, Hunter DJ, Innocenti F, Jenab M, Kaaks R, Key TJ, Khaw K-T, Klein EA, Kogevinas M, Krogh V, Kupcinskas J, Kurtz RC, LaCroix A, Landi MT, Landi S, Le Marchand L, Mambrini A, Mannisto S, Milne RL, Nakamura Y, Oberg AL, Owzar K, Patel AV, Peeters PHM, Peters U, Pezzilli R, Piepoli A, Porta M, Real FX, Riboli E, Rothman N, Scarpa A, Shu X-O, Silverman DT, Soucek P, Sund M, Talar-Wojnarowska R, Taylor PR, Theodoropoulos GE, Thornquist M, Tjønneland A, Tobias GS, Trichopoulos D, Vodicka P, Wactawski-Wende J, Wentzensen N, Wu C, Yu H, Yu K, Zeleniuch-Jacquotte A, Hoover R, Hartge P, Fuchs C, Chanock SJ, Stolzenberg-Solomon RS, Amundadottir LT. Genome-wide association study identifies multiple susceptibility loci for pancreatic cancer. Nat Genet 2014;46:994-1000.

10 Childs EJ, Mocci E, Campa D, Bracci PM, Gallinger S, Goggins M, Li D, Neale RE, Olson SH, Scelo G, Amundadottir LT, Bamlet WR, Bijlsma MF, Blackford A, Borges M, Brennan P, Brenner H, Bueno-de-Mesquita HB, Canzian F, Capurso G, Cavestro GM, Chaffee KG, Chanock SJ, Cleary SP, Cotterchio M, Foretova L, Fuchs C, Funel N, Gazouli M, Hassan M, Herman JM, Holcatova I, Holly EA, Hoover RN, Hung RJ, Janout V, Key TJ, Kupcinskas J, Kurtz RC, Landi S, Lu L, Malecka-Panas E, Mambrini A, MohelnikovaDuchonova B, Neoptolemos JP, Oberg AL, Orlow I, Pasquali C, Pezzilli R, Rizzato C, Saldia A, Scarpa A, Stolzenberg-Solomon RZ, Strobel O, Tavano F, Vashist YK, Vodicka P, Wolpin BM, Yu H, Petersen GM, Risch HA, Klein AP. Common variation at 2p13.3, $3 q 29,7 p 13$ and $17 q 25.1$ associated with susceptibility to pancreatic cancer. Nat Genet 2015:47:911-6.

11 Campa D, Rizzato C, Stolzenberg-Solomon R, Pacetti P, Vodicka P, Cleary SP, Capurso G, Bueno-de-Mesquita HBA, Werner J, Gazouli M, Butterbach K, Ivanauskas A, Giese N, Petersen GM, Fogar P, Wang Z, Bassi C, Ryska M, Theodoropoulos GE, Kooperberg C, Li D, Greenhalf W, Pasquali C, Hackert T, Fuchs CS, Mohelnikova-Duchonova B, Sperti C, Funel N, Dieffenbach AK, Wareham NJ, Buring J, Holcátová I, Costello E, Zambon C-F, Kupcinskas J, Risch HA, Kraft P, Bracci PM, Pezzilli R, Olson SH, Sesso HD, Hartge P, Strobel O, Małecka-Panas E, Visvanathan K, Arslan AA, Pedrazzoli S, Souček P, Gioffreda D, Key TJ, TalarWojnarowska R, Scarpa A, Mambrini A, Jacobs EJ, Jamroziak K, Klein A, Tavano F, Bambi F, Landi S, Austin MA, Vodickova L, Brenner H, Chanock SJ, Delle Fave G, Piepoli A, Cantore M, Zheng W, Wolpin BM, Amundadottir LT, Canzian F, Costello E, Zambon C-FF, Kupcinskas J, Risch HA, Kraft P, Bracci PM, Pezzilli R, Olson SH, Sesso HD, Hartge P, Strobel O, Visvanathan K, Arslan AA, Pedrazzoli S, Gioffreda D, Key TJ, Talar-Wojnarowska R, Scarpa A, Mambrini A, Jacobs EJ, Jamroziak K, Klein A, Tavano F, Bambi F, Landi S, Austin MA, Vodickova L, Brenner H, Chanock SJ, Delle Fave G, Piepoli A, Cantore M, Zheng W, Wolpin BM, Amundadottir LT, Canzian F. TERT gene harbors multiple variants associated with pancreatic cancer susceptibility. Int J Cancer 2015;137:2175-83.

12 Zhang M, Wang Z, Obazee O, Jia J, Childs EJ, Hoskins J, Figlioli G, Mocci E, Collins I, Chung CC, Hautman C, Arslan AA, Beane-Freeman L, Bracci PM, Buring J, Duell EJ Gallinger S, Giles GG, Goodman GE, Goodman PJ, Kamineni A, Kolonel LN, Kulke MH, Malats N, Olson SH, Sesso HD, Visvanathan K, White E, Zheng W, Abnet CC, Albanes $D$, Andreotti G, Brais L, Bueno-de-Mesquita HB, Basso D, Berndt SI, Boutron-Ruault M-C, Bijlsma MF, Brenner H, Burdette L, Campa D, Caporaso NE, Capurso G, Cavestro GM, Cotterchio M, Costello E, Elena J, Boggi U, Gaziano JM, Gazouli M, Giovannucci EL, Goggins M, Gross M, Haiman CA, Hassan M, Helzlsouer KJ, Hu N, Hunter DJ, Iskierka-Jazdzewska E, Jenab M, Kaaks R, Key TJ, Khaw K-T, Klein EA, Kogevinas M, Krogh V, Kupcinskas J, Kurtz RC, Landi MT, Landi S, Le Marchand L, Mambrini A, Mannisto S, Milne RL, Neale RE, Oberg AL, Panico S, Patel AV, Peeters PHM, Peters U, Pezzilli R, Porta M, Purdue M, Quiros JR, Riboli E, Rothman N, Scarpa A, Scelo G, Shu X-O, Silverman DT, Soucek P, Strobel O, Sund M, Małecka-Panas E, Taylor PR, Tavano F, Travis RC, Thornquist M, Tjønneland A, Tobias GS, Trichopoulos D, Vashist Y, Vodicka P, Wactawski-Wende J, Wentzensen N, Yu H, Yu K, Zeleniuch-Jacquotte A, Kooperberg C, Risch HA, Jacobs EJ, Li D, Fuchs C, Hoover R, Hartge P, Chanock SJ, Petersen GM, Stolzenberg-Solomon RS, Wolpin BM, Kraft P, Klein AP, Canzian F, Amundadottir LT. Three new pancreatic cancer susceptibility signals identified on chromosomes 1q32.1, 5p15.33 and 8q24.21. Oncotarget 2016:7:66328-43.

13 Klein AP, Wolpin BM, Risch HA, Stolzenberg-Solomon RZ, Mocci E, Zhang M, Canzian F, Childs EJ, Hoskins JW, Jermusyk A, Zhong J, Chen F, Albanes D, Andreotti G, Arslan AA, Babic A, Bamlet WR, Beane-Freeman L, Berndt SI, Blackford A, Borges M, Borgida A, Bracci PM, Brais L, Brennan P, Brenner H, Bueno-de-Mesquita B, Buring J, Campa D, Capurso G, Cavestro GM, Chaffee KG, Chung CC, Cleary S, Cotterchio M, Dijk F, Duell EJ, Foretova L, Fuchs C, Funel N, Gallinger S, M Gaziano JM, Gazouli M, Giles GG, Giovannucci E, Goggins M, Goodman GE, Goodman PJ, Hackert T, Haiman C, Hartge P, Hasan M, Hegyi P, Helzlsouer KJ, Herman J, Holcatova I, Holly EA, Hoover R, Hung RJ, Jacobs EJ, Jamroziak K, Janout V, Kaaks R, Khaw K-T, Klein EA, Kogevinas M, Kooperberg C, Kulke MH, Kupcinskas J, Kurtz RJ, Laheru D, Landi S, Lawlor RT, Lee I-M, LeMarchand L, Lu L, Malats N, Mambrini A, Mannisto S, Milne RL, MohelníkováDuchoňová B, Neale RE, Neoptolemos JP, Oberg AL, Olson SH, Orlow I, Pasquali C, Patel AV, Peters U, Pezzilli R, Porta M, Real FX, Rothman N, Scelo G, Sesso HD, Severi G, Shu X-O, Silverman D, Smith JP, Soucek P, Sund M, Talar-Wojnarowska R, Tavano F, Thornquist MD, Tobias GS, Van Den Eeden SK, Vashist Y, Visvanathan K, Vodicka P, Wactawski-Wende J, Wang Z, Wentzensen N, White E, Yu H, Yu K, Zeleniuch-Jacquotte A, Zheng W, Kraft P, Li D, Chanock S, Obazee O, Petersen GM, Amundadottir LT. Genome-wide meta-analysis identifies five new susceptibility loci for pancreatic cancer. Nat Commun 2018;9:556. 
14 Campa D, Matarazzi M, GreenhalfW, Bijlsma M, Saum K-U, Pasquali C, van Laarhoven H, Szentesi A, Federici F, Vodicka P, Funel N, Pezzilli R, Bueno-de-Mesquita HB, Vodickova L, Basso D, Obazee O, Hackert T, Soucek P, Cuk K, Kaiser J, Sperti C, Lovecek M, Capurso G, Mohelnikova-Duchonova B, Khaw K-T, König A-K, Kupcinskas J, Kaaks R, Bambi F, Archibugi L, Mambrini A, Cavestro GM, Landi S, Hegyi P, Izbicki JR, Gioffreda D, Zambon CF, Tavano F, Talar-Wojnarowska R, Jamroziak K, Key TJ, Fave GD, Strobel O, Jonaitis L, Andriulli A, Lawlor RT, Pirozzi F, Katzke V, Valsuani C, Vashist YK, Brenner $\mathrm{H}$, Canzian F. Genetic determinants of telomere length and risk of pancreatic cancer: a PANDoRA study. Int J Cancer 2019;144:1275-83.

15 Campa D, Pastore M, Gentiluomo M, Talar-Wojnarowska R, Kupcinskas J, MaleckaPanas E, Neoptolemos JP, Niesen W, Vodicka P, Fave GD, Bueno-de-Mesquita HB, Gazouli M, Pacetti P, Di Leo M, Ito H, Klüter H, Soucek P, Corbo V, Yamao K, Hosono S, Kaaks R, Vashist Y, Gioffreda D, Strobel O, Shimizu Y, Dijk F, Andriulli A, Ivanauskas A, Bugert P, Tavano F, Vodickova L, Zambon CF, Lovecek M, Landi S, Key TJ, Boggi U, Pezzilli R, Jamroziak K, Mohelnikova-Duchonova B, Mambrini A, Bambi F, Busch O, Pazienza V, Valente R, Theodoropoulos GE, Hackert T, Capurso G, Cavestro GM, Pasquali C, Basso D, Sperti C, Matsuo K, Büchler M, Khaw K-T, Izbicki J, Costello E, Katzke V, Michalski C, Stepien A, Rizzato C, Canzian F. Functional single nucleotide polymorphisms within the cyclin-dependent kinase inhibitor $2 \mathrm{~A} / 2 \mathrm{~B}$ region affect pancreatic cancer risk. Oncotarget 2016;7:57011-20.

16 Gentiluomo M, Peduzzi G, Lu Y, Campa D, Canzian F. Genetic polymorphisms in inflammatory genes and pancreatic cancer risk: a two-phase study on more than 14 000 individuals. Mutagenesis; 74.

17 Gentiluomo M, Lu Y, Canzian F, Campa D. Genetic variants in taste-related genes and risk of pancreatic cancer. Mutagenesis 2019;34:391-4.

18 Wolpin BM, Chan AT, Hartge P, Chanock SJ, Kraft P, Hunter DJ, Giovannucci EL, Fuchs CS. ABO blood group and the risk of pancreatic cancer. J Natl Cancer Inst 2009;101:424-31.

19 Marcus DM. The ABO and Lewis blood-group system. Immunochemistry, genetics and relation to human disease. N Engl J Med 1969:280:994-1006.

20 Wolpin BM, Kraft P, Xu M, Steplowski E, Olsson ML, Arslan AA, Bueno-de-Mesquita HB, Gross M, Helzlsouer K, Jacobs EJ, LaCroix A, Petersen G, Stolzenberg-Solomon RZ, Zheng W, Albanes D, Allen NE, Amundadottir L, Austin MA, Boutron-Ruault $\mathrm{M}-\mathrm{C}$, Buring JE, Canzian F, Chanock SJ, Gaziano JM, Giovannucci EL, Hallmans G, Hankinson SE, Hoover RN, Hunter DJ, Hutchinson A, Jacobs KB, Kooperberg C, Mendelsohn JB, Michaud DS, Overvad K, Patel AV, Sanchéz M-J, Sansbury L, Shu X-O, Slimani N, Tobias GS, Trichopoulos D, Vineis P, Visvanathan K, Virtamo J, Wactawski-Wende J, Watters J, Yu K, Zeleniuch-Jacquotte A, Hartge P, Fuchs CS. Variant ABO blood group alleles, secretor status, and risk of pancreatic cancer: results from the pancreatic cancer cohort Consortium. Cancer Epidemiol Biomarkers Prev 2010;19:3140-9.

21 Wolpin BM, Kraft P, Gross M, Helzlsouer K, Bueno-de-Mesquita HB, Steplowski E, Stolzenberg-Solomon RZ, Arslan AA, Jacobs EJ, Lacroix A, Petersen G, Zheng W, Albanes D, Allen NE, Amundadottir L, Anderson G, Boutron-Ruault M-C, Buring JE, Canzian F, Chanock SJ, Clipp S, Gaziano JM, Giovannucci EL, Hallmans G, Hankinson SE, Hoover RN, Hunter DJ, Hutchinson A, Jacobs K, Kooperberg C, Lynch SM, Mendelsohn JB, Michaud DS, Overvad K, Patel AV, Rajkovic A, Sanchéz M-J, Shu X-O, Slimani N, Thomas G, Tobias GS, Trichopoulos D, Vineis P, Virtamo J, Wactawski-Wende J, Yu K, Zeleniuch-Jacquotte A, Hartge P, Fuchs CS. Pancreatic cancer risk and ABO blood group alleles: results from the pancreatic cancer cohort Consortium. Cancer Res 2010;70:1015-23.

22 Rizzato C, Campa D, Pezzilli R, Soucek P, Greenhalf W, Capurso G, Talar-Wojnarowska R, Heller A, Jamroziak K, Khaw K-T, Key TJ, Bambi F, Landi S, Mohelnikova-Duchonova B, Vodickova L, Büchler MW, Bugert P, Vodicka P, Neoptolemos JP, Werner J, Hoheisel JD, Bauer AS, Giese N, Canzian F. ABO blood groups and pancreatic cancer risk and survival: results from the pancreatic disease research (PANDoRA) Consortium. Oncol Rep 2013;29:1637-44.

23 Lindström S, Schumacher FR, Cox D, Travis RC, Albanes D, Allen NE, Andriole G, Berndt SI, Boeing H, Bueno-de-Mesquita HB, Crawford ED, Diver WR, Gaziano JM, Giles GG, Giovannucci E, Gonzalez CA, Henderson B, Hunter DJ, Johansson M, Kolonel LN, Ma J, Le Marchand L, Pala V, Stampfer M, Stram DO, Thun MJ, Tjonneland A, Trichopoulos D, Virtamo J, Weinstein SJ, Willett WC, Yeager M, Hayes RB, Severi G, Haiman CA, Chanock SJ, Kraft P. Common genetic variants in prostate cancer risk prediction-results from the NCl Breast and Prostate Cancer Cohort Consortium (BPC3). Cancer Epidemiol Biomarkers Prev 2012;21:437-44.

24 Hüsing A, Canzian F, Beckmann L, Garcia-Closas M, Diver WR, Thun MJ, Berg CD, Hoover RN, Ziegler RG, Figueroa JD, Isaacs C, Olsen A, Viallon V, Boeing H, Masala G, Trichopoulos D, Peeters PHM, Lund E, Ardanaz E, Khaw K-T, Lenner P, Kolonel LN, Stram DO, Le Marchand L, McCarty CA, Buring JE, Lee I-M, Zhang S, Lindström S, Hankinson SE, Riboli E, Hunter DJ, Henderson BE, Chanock SJ, Haiman CA, Kraft P, Kaaks R, BPC3. Prediction of breast cancer risk by genetic risk factors, overall and by hormone receptor status. J Med Genet 2012;49:601-8.

25 Mavaddat N, Pharoah PDP, Michailidou K, Tyrer J, Brook MN, Bolla MK, Wang Q, Dennis J, Dunning AM, Shah M, Luben R, Brown J, Bojesen SE, Nordestgaard BG, Nielsen SF, Flyger H, Czene K, Darabi H, Eriksson M, Peto J, Dos-Santos-Silva I, Dudbridge F, Johnson N, Schmidt MK, Broeks A, Verhoef S, Rutgers EJ, Swerdlow A, Ashworth A, Orr N, Schoemaker MJ, Figueroa J, Chanock SJ, Brinton L, Lissowska J, Couch FJ, Olson JE, Vachon C, Pankratz VS, Lambrechts D, Wildiers H, Van Ongeval
C, van Limbergen E, Kristensen V, Grenaker Alnæs G, Nord S, Borresen-Dale A-L, Nevanlinna H, Muranen TA, Aittomäki K, Blomqvist C, Chang-Claude J, Rudolph A Seibold P, Flesch-Janys D, Fasching PA, Haeberle L, Ekici AB, Beckmann MW, Burwinkel B, Marme F, Schneeweiss A, Sohn C, Trentham-Dietz A, Newcomb P, Titus L, Egan KM, Hunter DJ, Lindstrom S, Tamimi RM, Kraft P, Rahman N, Turnbull C, Renwick A, Seal S, Li J, Liu J, Humphreys K, Benitez J, Pilar Zamora M, Arias Perez Jl, Menéndez P, Jakubowska A, Lubinski J, Jaworska-Bieniek K, Durda K, Bogdanova NV, Antonenkova NN, Dörk T, Anton-Culver H, Neuhausen SL, Ziogas A, Bernstein L, Devilee P, Tollenaar RAEM, Seynaeve C, van Asperen CJ, Cox A, Cross SS, Reed MWR, Khusnutdinova E, Bermisheva M, Prokofyeva D, Takhirova Z, Meindl A, Schmutzler RK, Sutter C, Yang R, Schürmann P, Bremer M, Christiansen $H$, Park-Simon T-W, Hillemanns $P$, Guénel $P$, Truong T, Menegaux F, Sanchez M, Radice P, Peterlongo P, Manoukian S, Pensotti V, Hopper IL, Tsimiklis H, Apicella C, Southey MC, Brauch H, Brüning T, Ko Y-D, Sigurdson AJ, Doody MM, Hamann U, Torres D, Ulmer H-U, Försti A, Sawyer EJ, Tomlinson I, Kerin MJ, Miller N, Andrulis IL, Knight JA, Glendon G, Marie Mulligan A, Chenevix-Trench G, Balleine R, Giles GG, Milne RL, McLean C, Lindblom A, Margolin S, Haiman CA, Henderson BE, Schumacher F, Le Marchand L, Eilber U, Wang-Gohrke S, Hooning MJ, Hollestelle A, van den Ouweland AMW, Koppert LB, Carpenter J, Clarke C, Scott R, Mannermaa A, Kataja V, Kosma V-M, Hartikainen JM, Brenner H, Arndt V, Stegmaier C, Karina Dieffenbach A, Winqvist R, Pylkäs K, Jukkola-Vuorinen A, Grip M, Offit K, Vijai J, Robson M, Rau-Murthy R, Dwek M, Swann R, Annie Perkins K, Goldberg MS, Labrèche F, Dumont M, Eccles DM, Tapper WJ, Rafiq S, John EM, Whittemore AS, Slager S, Yannoukakos D, Toland AE, Yao S, Zheng W, Halverson SL, González-Neira A, Pita G, Rosario Alonso M, Álvarez N, Herrero D, Tessier DC, Vincent D, Bacot F, Luccarini C, Baynes C, Ahmed S, Maranian M, Healey CS, Simard J, Hall P, Easton DF, Garcia-Closas M. Prediction of breast cancer risk based on profiling with common genetic variants, J Natl Cancer Inst 2015;107. doi:10.1093/jnci/djv036. [Epub ahead of print: 08 Apr 2015].

26 Maas P, Barrdahl M, Joshi AD, Auer PL, Gaudet MM, Milne RL, Schumacher FR, Anderson WF, Check D, Chattopadhyay S, Baglietto L, Berg CD, Chanock SJ, Cox DG, Figueroa JD, Gail MH, Graubard BI, Haiman CA, Hankinson SE, Hoover RN, Isaacs C, Kolonel LN, Le Marchand L, Lee I-M, Lindström S, Overvad K, Romieu I, Sanchez M-J, Southey MC, Stram DO, Tumino R, VanderWeele TJ, Willett WC, Zhang S, Buring JE, Canzian F, Gapstur SM, Henderson BE, Hunter DJ, Giles GG, Prentice RL, Ziegler RG, Kraft P, Garcia-Closas M, Chatterjee N. Breast cancer risk from modifiable and Nonmodifiable risk factors among white women in the United States. JAMA Oncol 2016:2:1295-302.

27 Mavaddat N, Michailidou K, Dennis J, Lush M, Fachal L, Lee A, Tyrer JP, Chen T-H, Wang Q, Bolla MK, Yang X, Adank MA, Ahearn T, Aittomäki K, Allen J, Andrulis IL, Anton-Culver H, Antonenkova NN, Arndt V, Aronson KJ, Auer PL, Auvinen P, Barrdahl $M$, Beane Freeman LE, Beckmann MW, Behrens S, Benitez J, Bermisheva M, Bernstein L, Blomqvist C, Bogdanova NV, Bojesen SE, Bonanni B, Børresen-Dale A-L, Brauch $\mathrm{H}$, Bremer M, Brenner H, Brentnall A, Brock IW, Brooks-Wilson A, Brucker SY, Brüning T, Burwinkel B, Campa D, Carter BD, Castelao JE, Chanock SJ, Chlebowski R, Christiansen H, Clarke CL, Collée JM, Cordina-Duverger E, Cornelissen S, Couch FJ, Cox A, Cross SS, Czene K, Daly MB, Devilee P, Dörk T, Dos-Santos-Silva I, Dumont M, Durcan L, Dwek M, Eccles DM, Ekici AB, Eliassen AH, Ellberg C, Engel C, Eriksson M, Evans DG, Fasching PA, Figueroa J, Fletcher O, Flyger H, Försti A, Fritschi L, Gabrielson M, Gago-Dominguez M, Gapstur SM, García-Sáenz JA, Gaudet MM, Georgoulias V, Giles GG, Gilyazova IR, Glendon G, Goldberg MS, Goldgar DE, González-Neira A, Grenaker Alnæs GI, Grip M, Gronwald J, Grundy A, Guénel P, Haeberle L, Hahnen E, Haiman CA, Håkansson N, Hamann U, Hankinson SE, Harkness EF, Hart SN, He W, Hein A, Heyworth J, Hillemanns P, Hollestelle A, Hooning MJ, Hoover RN, Hopper JL, Howell A, Huang G, Humphreys K, Hunter DJ, Jakimovska M, Jakubowska A, Janni W, John EM, Johnson N, Jones ME, Jukkola-Vuorinen A, Jung A, Kaaks R, Kaczmarek K, Kataja V, Keeman R, Kerin MJ, Khusnutdinova E, Kiiski JI, Knight JA, Ko Y-D, Kosma V-M, Koutros S, Kristensen VN, Krüger U, Kühl T, Lambrechts D, Le Marchand L, Lee E, Lejbkowicz F, Lilyquist J, Lindblom A, Lindström S, Lissowska J, Lo W-Y, Loibl S, Long J, Lubiński J, Lux MP, Maclnnis RJ, Maishman T, Makalic E, Maleva Kostovska I, Mannermaa A, Manoukian S, Margolin S, Martens JWM, Martinez ME, Mavroudis D, McLean C, Meindl A, Menon U, Middha P, Miller N, Moreno F, Mulligan AM, Mulot C, Muñoz-Garzon VM, Neuhausen SL, Nevanlinna H, Neven P, Newman WG, Nielsen SF, Nordestgaard BG, Norman A, Offit K, Olson JE, Olsson H, Orr N, Pankratz VS, Park-Simon T-W, Perez JIA, Pérez-Barrios C, Peterlongo P, Peto J, Pinchev M, PlaseskaKaranfilska D, Polley EC, Prentice R, Presneau N, Prokofyeva D, Purrington K, Pylkäs K, Rack B, Radice P, Rau-Murthy R, Rennert G, Rennert HS, Rhenius V, Robson M, Romero A, Ruddy KJ, Ruebner M, Saloustros E, Sandler DP, Sawyer EJ, Schmidt DF, Schmutzler RK, Schneeweiss A, Schoemaker MJ, Schumacher F, Schürmann P, Schwentner L, Scott C, Scott RJ, Seynaeve C, Shah M, Sherman ME, Shrubsole MJ, Shu X-O, Slager S, Smeets A, Sohn C, Soucy P, Southey MC, Spinelli JJ, Stegmaier C, Stone J, Swerdlow AJ, Tamimi RM, Tapper WJ, Taylor JA, Terry MB, Thöne K, Tollenaar RAEM, Tomlinson I, Truong T, Tzardi M, Ulmer H-U, Untch M, Vachon CM, van Veen EM, Vijai J, Weinberg CR, Wendt C, Whittemore AS, Wildiers H, Willett W, Winqvist R, Wolk A, Yang XR, Yannoukakos D, Zhang Y, Zheng W, Ziogas A, Dunning AM, Thompson DJ, ChenevixTrench G, Chang-Claude J, Schmidt MK, Hall P, Milne RL, Pharoah PDP, Antoniou AC, Chatterjee N, Kraft P, García-Closas M, Simard J, Easton DF, ABCTB Investigators, kConFab/AOCS Investigators, NBCS Collaborators. Polygenic risk scores for prediction of breast cancer and breast cancer subtypes. Am J Hum Genet 2019;104:21-34. 
28 Hüsing A, Dossus L, Ferrari P, Tjønneland A, Hansen L, Fagherazzi G, Baglietto L, Schock H, Chang-Claude J, Boeing H, Steffen A, Trichopoulou A, Bamia C, Katsoulis M, Krogh V, Palli D, Panico S, Onland-Moret NC, Peeters PH, Bueno-de-Mesquita HB, Weiderpass E, Gram IT, Ardanaz E, Obón-Santacana M, Navarro C, Sánchez-Cantalejo E, Etxezarreta N, Allen NE, Khaw KT, Wareham N, Rinaldi S, Romieu I, Merritt MA, Gunter M, Riboli E, Kaaks R. An epidemiological model for prediction of endometrial cancer risk in Europe. Eur J Epidemiol 2016;31:51-60.

29 Klein AP, Lindström S, Mendelsohn JB, Steplowski E, Arslan AA, Bueno-de-Mesquita HB, Fuchs CS, Gallinger S, Gross M, Helzlsouer K, Holly EA, Jacobs EJ, Lacroix A, Li D, Mandelson MT, Olson SH, Petersen GM, Risch HA, Stolzenberg-Solomon RZ, Zheng W, Amundadottir L, Albanes D, Allen NE, Bamlet WR, Boutron-Ruault M-C, Buring JE, Bracci PM, Canzian F, Clipp S, Cotterchio M, Duell EJ, Elena J, Gaziano JM, Giovannucci EL, Goggins M, Hallmans G, Hassan M, Hutchinson A, Hunter DJ, Kooperberg C, Kurtz RC, Liu S, Overvad K, Palli D, Patel AV, Rabe KG, Shu X-O, Slimani N, Tobias GS, Trichopoulos D, Van Den Eeden SK, Vineis P, Virtamo J, Wactawski-Wende J, Wolpin BM, Yu H, Yu K, Zeleniuch-Jacquotte A, Chanock SJ, Hoover RN, Hartge P, Kraft P. An absolute risk model to identify individuals at elevated risk for pancreatic cancer in the general population. PLoS One 2013;8:e72311.

30 Campa D, Rizzato C, Capurso G, Giese N, Funel N, Greenhalf W, Soucek P, Gazouli M, Pezzilli R, Pasquali C, Talar-Wojnarowska R, Cantore M, Andriulli A, Scarpa A, Jamroziak K, Delle Fave G, Costello E, Khaw K-T, Heller A, Key TJ, Theodoropoulos G, Malecka-Panas E, Mambrini A, Bambi F, Landi S, Pedrazzoli S, Bassi C, Pacetti P, Piepoli A, Tavano F, di Sebastiano P, Vodickova L, Basso D, Plebani M, Fogar P, Büchler MW, Bugert P, Vodicka P, Boggi U, Neoptolemos JP, Werner J, Canzian F. Genetic susceptibility to pancreatic cancer and its functional characterisation: the pancreatic disease research (PANDoRA) Consortium. Dig Liver Dis 2013;45:95-9.

31 Bycroft C, Freeman C, Petkova D, Band G, Elliott LT, Sharp K, Motyer A, Vukcevic D, Delaneau O, O'Connell J, Cortes A, Welsh S, Young A, Effingham M, McVean G, Leslie S, Allen N, Donnelly P, Marchini J. The UK Biobank resource with deep phenotyping and genomic data. Nature 2018;562:203-9.

321000 Genomes Project Consortium, Abecasis GR, Altshuler D, Auton A, Brooks LD, Durbin RM, Gibbs RA, Hurles ME, McVean GA. A map of human genome variation from population-scale sequencing. Nature 2010;467:1061-73.

33 Canto MI, Harinck F, Hruban RH, Offerhaus GJ, Poley J-W, Kamel I, Nio Y, Schulick RS, Bassi C, Kluijt I, Levy MJ, Chak A, Fockens P, Goggins M, Bruno M, International
Cancer of Pancreas Screening (CAPS) Consortium. International cancer of the pancreas screening (CAPS) Consortium Summit on the management of patients with increased risk for familial pancreatic cancer. Gut 2013;62:339-47.

34 Janssens ACJW, Aulchenko YS, Elefante S, Borsboom GJJM, Steyerberg EW, van Duijn CM. Predictive testing for complex diseases using multiple genes: fact or fiction? Genet Med 2006;8:395-400.

35 Wray NR, Goddard ME, Visscher PM. Prediction of individual genetic risk to disease from genome-wide association studies. Genome Res 2007;17:1520-8.

36 Pharoah PDP, Antoniou AC, Easton DF, Ponder BAJ. Polygenes, risk prediction, and targeted prevention of breast cancer. N Engl J Med 2008;358:2796-803.

37 Wacholder S, Hartge P, Prentice R, Garcia-Closas M, Feigelson HS, Diver WR, Thun MJ, Cox DG, Hankinson SE, Kraft P, Rosner B, Berg CD, Brinton LA, Lissowska J, Sherman ME, Chlebowski R, Kooperberg C, Jackson RD, Buckman DW, Hui P, Pfeiffer R, Jacobs KB, Thomas GD, Hoover RN, Gail MH, Chanock SJ, Hunter DJ. Performance of common genetic variants in breast-cancer risk models. $N$ Engl J Med 2010;362:986-93.

38 Figlioli G, Chen B, Elisei R, Romei C, Campo C, Cipollini M, Cristaudo A, Bambi F, Paolicchi E, Hoffmann P, Herms S, Kalemba M, Kula D, Pastor S, Marcos R, Velázquez A, Jarząb B, Landi S, Hemminki K, Gemignani F, Försti A. Novel genetic variants in differentiated thyroid cancer and assessment of the cumulative risk. Sci Rep 2015;5:8922.

$39 \mathrm{Gu}$ W, Pepe MS. Estimating the capacity for improvement in risk prediction with a marker. Biostatistics 2009;10:172-86

40 Pearce CL, Rossing MA, Lee AW, Ness RB, Webb PM, Chenevix-Trench G, Jordan SM, Stram DA, Chang-Claude J, Hein R, Nickels S, Lurie G, Thompson PJ, Carney ME, Goodman MT, Moysich K, Hogdall E, Jensen A, Goode EL, Fridley BL, Cunningham JM, Vierkant RA, Weber RP, Ziogas A, Anton-Culver H, Gayther SA, Gentry-Maharaj A, Menon U, Ramus SJ, Brinton L, Wentzensen N, Lissowska J, Garcia-Closas M, Massuger LFAG, Kiemeney LALM, Van Altena AM, Aben KKH, Berchuck A, Doherty JA, Iversen E, McGuire V, Moorman PG, Pharoah P, Pike MC, Risch H, Sieh W, Stram DO, Terry KL, Whittemore A, Wu AH, Schildkraut JM, Kjaer SK, for Australian Cancer Study (Ovarian Cancer), Australian Ovarian Cancer Study Group, Ovarian Cancer Association Consortium. Combined and interactive effects of environmental and GWAS-identified risk factors in ovarian cancer. Cancer Epidemiol Biomarkers Prev 2013;22:880-90. 